\title{
Strategi Komunikasi Polresta jaka Kota Terhadap Larangan Mudik Idul Fitri 2021 dalam Upaya Pengendalian Covid-19
}

\author{
Farhan Walyudin, Eka Yusup, Ana Fitriana Poerana \\ Universitas Singaperbangsa Karawang, Jl. HS.Ronggo Waluyo, Puseurjaya, Kec. Telukjambe Timur., \\ Kabupaten Karawang, Jawa Barat 41361. Indonesia. \\ email : farhan.walyudin17067@student.unsika.ac.id
}

\begin{abstract}
ABSTRAK
Penelitian ini bertujuan untuk memaparkan bagaimana strategi komunikasi yang dilakukan oleh Polresta Bogor Kota terhadap Larangan mudik 2021 untuk pencegahan penyebaran Covid-19. Penelitian ini menggunakan metode deskriptif kualitatif, yang menggunakan data analisis dari hasil wawancara dan observasi terhadap objek. Situasi Covid-19 membuat Masyarakat Indonesia tahun 2021 ini tidak melakukan mudik hari raya idul fitri. hal ini di karena untuk menghentikan laju Penyebaran Covid-19 lalu pemerintah pun melarang untuk tidak melakukan mudik 2021. Menurut peneliti kendala yang perlu menjadi perhatian adalah masyarakat akan tetap melakukan mudik pra dan pasca penetapan larangan mudik walau mudik itu dilarang dan hal ini akan menyebabkan intensitas mobilitas di jalanan akan padat. Strategi komunikasi yang dilakukan oleh kepolisian Bogor Kota untuk mencegah pemudik dilakukan secara maksimal dan efektif untuk disampaikan kepada masyarakat, sebelum menyampaikan pesan kepolisian mempersiapkan strategi dengan matang seperti melakukan sosialisasi baik secara langsung maupun melalui suatu media serta melakukan berbagai giat operasi guna mencegah masyarakat melakukan mudik.
\end{abstract}

Kata kunci: Strategi komunikasi, mudik, Covid-19

\begin{abstract}
This study aims to explain how the communication strategy carried out by the Bogor City Police regarding the 2021 Homecoming Ban to prevent the spread of Covid-19. This study uses a qualitative descriptive method, which uses data analysis from interviews and observations of objects. The Covid19 situation has prevented the Indonesian people in 2021 from going home for Eid al-Fitr. This is because to stop the spread of Covid-19, the government also forbids not to do homecoming in 2021. According to researchers, the obstacle that needs attention is that people will continue to carry out homecoming before and after the stipulation of the ban on going home even though going home is prohibited and this will cause intensity mobility on the streets will be congested. The communication strategy carried out by the Bogor City police to prevent travelers is carried out optimally and effectively to be conveyed to the public, before conveying a message the police prepare carefully for strategies such as conducting socialization either directly or through a media and carrying out various active operations to prevent people from going home.
\end{abstract}

Keywords: Communication Strategy, mudik, Covid-19 


\section{Introduction}

Indonesia memiliki banyak tradisi di setiap tahunnya, salah satunya yaitu mudik. Mudik diartikan sebagai "pulang kampung", meski secara harfiah dari kata "udik atau kampung", sehingga makna mudik bisa diartikan sebagai "pulang kampung” yang selalu dilakukan orang Indonesia sebelum hari raya Idul Fitri. Pada umumnya mudik lebaran dilakukan oleh seluruh umat Islam yang tinggal di luar kota asalnya atau yang tinggal jauh dari kampung halamannya. Kebiasaan ini dilaksanakan mulai 7 (tujuh) hari sebelum Lebaran hingga 7 (tujuh) hari setelah lebaran. Jangka waktu untuk kembali ke tempat asal mereka berbeda-beda untuk setiap orang, tergantung pada jangka waktu cuti yang diberikan oleh pemberi kerja atau tempat kerja di kota. Jangka waktu seminggu sebelum hingga setelahnya merupakan jangka waktu terlama yang digunakan oleh mereka yang menempuh perjalanan mudik lebaran (Ari Purwanto Sarwo Prasojo, Yulinda Nurul Aini, 2020).

Fenomena mudik di Indonesia sudah menjadi tradisi masyarakat Indonesia khususnya saat Idul Fitri. Hampir setiap tahun arus mudik di Indonesia semakin meningkat dari tahun ke tahun, masyarakat melakukan mudik yaitu untuk berkumpul dengan keluarga sambil merayakan Idul Fitri bersama keluarga. Seperti data yang di dapat dari kementrian perhubungan (kemenhub) bahwa jumlah masyarakat yang melakukan mudik pada tahun 2019 pada rentan waktu hari ke tujuh sebelum lebaran dan hari ke tujuh setelah lebaran sebanyak 7,2 juta orang melakukan mudik Dengan asumsi penumpang melakukan perjalanan dari Jakarta dan sekitarnya ke kampung halaman mereka di Jawa atau Sumatera dan untuk penumpang udara sebanyak 1,5 juta orang. Serta jumlah penumpang angkutan kereta api dan laut mengalami peningkatan pada tahun 2019.

Pada tahun 2020 Kementrian Perhubungan (kemenhub) mencatat pada periode arus mudik dan balik 2020 mengalami penurunan untuk wilayah jabodetabek yaitu berkisar 60-70\% di bandingkan tahun lalu pada periode $\mathrm{H}-7$ sebelum idul fitri dan $\mathrm{H}+7$ setelah idul fitri. Pada arus mudik 2020 diperkirakan mencapai 552.759 yang melakukan mudik melalui jalan tol dan pada arus balik mudik 2020 mengalami penurunan berkisar $70 \%$ yaitu mencapai 448.380 kendaraan. Menhub juga menambahkan kendaraan yang keluar melalui jalan arteri mencapai 428.380 turun 66,3\% dan kendaraan masuk mencapai 206.064 kendaraan turun 74,6\% dibandingkan tahun lalu. Hal ini dikarnakan pada tahun 2020 ada larangan mudik pada masa pembatasan sosial bersekala besar 2020 (Kominfo, 2021).

Akibat dampak mudik 2020 jumlah kasus covid-19 mengalami kelonjakan. Menurut data kasus Covid-19 rata-rata perminggu mencapai 53,6\% kasus, lalu pada priode keempat setelah lebaran mengalami lonjakan rata-rata 69\%. Selanjutnya kasus baru mingguan pada 
liburan idulfitri 2020 sebesar $49 \%$ dan 60\% pada priode minggu keempat (Kompas Pedia, 2021). Lalu berdasarkan data satgas Covid-19 rata-rata kasus perharinya mencapai 63\%-93\% dengan penambahan kasus mingguan antara 2.889-3.917 lalu untuk kasus persentase kematian mingguan rata-rata 28-66\% (Kominfo, 2021)

Pada hari Jumat tanggal 25 Maret 2021 pemerintah resmi menerapkan kebijakan terkait larangan mudik yang berlaku untuk seluruh masyarakat Indonesia. Larangan mudik ini berlaku mulai dari 6-17 Mei 2021 dan pada tanggal tersebut masyarakat dihimbau tetap di rumah dan tidak ke mana-mana. karena pada tanggal 6 sampai 17 Mei 2021 tersebut aktivitas mudik lebaran akan dibatasi, guna menekan laju penyebaran Covid-19 yang ditaksir pada masa libur panjang seperti Hari Raya Idul Fitri selalu mengalami peningkatan (Satgas Covid 19, 2021). Lalu salah satu yang melatar belakangi adanya surat edaran larangan mudik nomor 13 tahun 2021 yaitu pada point 1 bahwa menurut hasil survei yang dilakukan oleh pasca penetapan peniadaan mudik bahwa akan ada masyarakat yang akan melakukan mudik 2021 sebelum hari raya idul fitri 2021 pada rentan waktu H-7 dan H+7 pemberlakuan peniadaan mudik. Serta dalam point ke 3 dari surat larangan mudik nomor 13 tahun 2021 bahwa hari raya idul fitri akan berpotensi meningkatkan resiko laju penularan Covid-19 dalam kegiatan keagamaan maupun kekeluargaan maka peraturan ini di buat.

Oleh karena itu, instansi kepolisian termasuk Polres Bogor Kota salah satu komunikator berperan sangat penting dalam menjalankan tugas terkait larangan mudik Lebaran 2021, karena kepolisian merupakan salah satu instansi yang bergerak dalam pekerjaan di bidang hukum, pelayanan, dan keamanan. Lembaga kepolisian memainkan peran penting dalam tugas ini, terlebih lagi yang disebutkan tadi bahwa hari raya idul fitri tahun lalu 2020 mengalami lonjakan kasus Covid-19 karna hari raya idul fitri dan mobilitas yang sangat tinggi di Jabodetabek. Dalam hal ini Jika tidak di atasi dengan baik akan berdampak pada wilayah Kota Bogor. Lalu juga seperti yang di ungkapkan oleh Dinas Perhubungan Kota Bogor Devisi lalulintas mengatakan di Kota Bogor banyak masyarakat luar Bogor yg tinggal di kota Bogor untuk mengontrak, ada juga masyarakat yang bukan orang Bogor yang bekerja di Bogor atau pun sebaliknya ada juga masyarakat Kota Bogor yang mempunyai pekerjaan di luar kota Bogor. Serta Bogor merupakan salah satu wilayah penyanggah ibu kota yaitu Jakarta dalam hal ini akan berpotensi banyak masyarakat yang akan melakukan mudik.

Kota-kota besar memiliki simpul penyebaran Covid-19 dimasa pandemi ini, dikarenakan kegiatan perekonomian dilakukan di kota. Saat ini, mobilitas penduduk yang tinggi di perkotaan menjadi faktor utama penyebaran Covid-19. Sejumlah penelitian menunjukkan bahwa mobilitas penduduk memainkan peran penting dalam penyebaran 
epidemi. Dalam hal ini, fenomena mudik dinilai sangat mengkhawatirkan karena dapat menyebarkan Covid-19. Khususnya di pulau Jawa memili tingkat penyebaran yang rawan di bandingkan dengan kota atau daerah lain dikarenakan di pulau Jawa memiliki mobilitas yang bisa dikatakan tinggi (Ari Purwanto Sarwo Prasojo, Yulinda Nurul Aini, 2020)

Polres Bogor juga harus mewaspadai hasil survei yang dilakukan Badan Penelitian dan Pengembangan Kementerian Perhubungan Republik Indonesia terhadap masyarakat yang akan mudik sebelum Lebaran, dan sekitar 11\% masyarakat akan melakukan mudik. Meski kegiatan mudik seperti ini dilarang, namun masih ada sekelompok masyarakat yang akan tetap mudik di hari raya Idul Fitri. Ketidak patuhan banyak masyarakat akan melakukan mudik dalam hal ini akan berpotensi adanya penyebaran Covid-19 semakin meluas dan akan sangat berbahaya.

Maka dari itu Kunci keberhasilan dari sosialisasi dan untuk menginformasikan terkait larangan mudik 2021 Polresta Bogor Kota harus adanya kegiatan strategi komunikasi. Strategi komunikasi adalah sepenuhnya merupakan keputusan sementara atas tindakan yang akan dijalankan untuk mencapai suatu target (Bulkis, 2018). Kegiatan menginformasikan pesan lazim digunakan oleh seseorang ataupun instansi untuk membujuk atau mempersuasi komunikan agar membaca pesan yang mereka sampaikan.

Kegiatan untuk menginformasikan dan mensosialisasikan berkaitan erat dengan proses komunikasi persuasif. Selain itu agar pesan bisa tersampaikan dengan baik kepada komunikan bisa berlangsung efektif dan berhasil. Komunikasi yang dilakukan memerlukan strategi komunikasi yang baik. Maka tujuan dari penelitian ini adalah untuk mengetahui strategi komunikasi yang dilakukan oleh Polresta Bogor Kota terhadap larangan mudik 2021 dalam upaya pencegahan penyebaran Covid-19.

\section{Literature Review}

\section{Strategi Komunikasi}

Istilah strategi komunikasi dalam (Yunus, 2016) terdiri atas dua buah kata yaitu strategi dan komunikasi. Kata 'strategi' itu sendiri banyak dikemukakan oleh banyak pakar, salah satunya dalam artikel yang dikemukakan oleh Porter 2012 yang berjudul Strategi Kompetitif Harvard Business Review menjelaskan strategi yaitu sikap yang berbeda untuk mendapatkan nilai yang istimewa. menurut Arthur A.J (2007) menjelaskan bahwa strategi merupakan suatu kegiatan yang mempunyai banyak saingan dengan pendekatan bisnis untuk mencapai suatu tujuan. Kemudian kata selanjutnya adalah 'Komunikasi'. Definisi Komunikasi merupakan seni untuk menyampaikan suatu informasi, gagasan, pandangan kepada orang lain (komunikan) agar mereka dapat mereka memahami, mengapresiasi, dan dapat menerima informasi tersebut 
dengan baik.

Strategi komunikasi dalam (Bulkis, 2018) sepenuhnya merupakan keputusan sementara atas tindakan yang akan dijalankan untuk mencapai suatu target, oleh karena itu merancang strategi komunikasi agar efektif berarti harus melihat kondisi dan situasi (ruang dan waktu) yang akan terjadi di masa. 26 Adanya strategi komunikasi ini, artinya dapat dicapai dengan beberapa cara, menggunakan komunikasi secara langsung untuk membentuk perubahan diri dengan mudah

Effendy juga mengemukakan bahwa strategi komunikasi yaitu Untuk mencapai tujuan yang telah di rencanakan di perlukan strategi komunikasi yang menggabungkan antara perencanaan komunikasi (communication planning) dan manajemen komunikasi (communication management) (Effendy, 2009).

\section{Methods}

Penelitian ini menggunakan jenis penelitian deskriptif kualitatif. Penelitian kualitatif bersifat subjektif yang dilirik dari sudut pandang partisipan secara deskriptif yang menggambarkan suatu permasalahan sesuai dengan adanya fakta dilapangan. Penelitian dilakukan pada objek Polresta Bogor Kota. pada penelitian ini diharapkan dapat menggambarkan adanya strategi komunikasi Polresta Bogor Kota terhadap larangan mudik 2021 dalam upaya pengendalian Covid-19. Wawancara dilakukan kepada Kepala Humas Polresta Bogor Kota dan anggota Humas Polresta Bogor Kota yang di laksanakan pada tanggal 3Juni 2021 secara In-Depth Interview atau wawancara secara mendalam. Wawancara adalah proses menggali informasi secara mendalam, terbuka dan bebas (Moleong, 2017).

Metode yang dilakukan secara observasi ini dilakukan sebagai pencatatan bagian atau hal yang bersifat spesifik pada objek yaitu Kepolisian yang melakukan suatu Kegiatan penanganan terkait larangan mudik 2021, pada observasi ini dibarengi dengan dokumentasi Kepolisian dalam penanganan mudik 2021. Metode dokumentasi digunakan juga untuk mengumpulkan data yang berkaitan dengan objek penelitian seperti foto, gambar, catatan dan lain sebagainya.

Bagaimana khalayak sasaran yang lebih besar dapat dijangkau secara lebih efektif seperti Metode wawancara dengan objek juga dilakukan oleh peneliti sebagai hasil untuk mendapatkan jawaban dari pertanyaan yang berkaitan dengan penelitian ini sehingga penelitian ini dapat memberikan alasan objek dalam membahas strategi komunikasi Polresta Bogor Kota terhadap larangan mudik 2021. Setelah semua data terkumpul, peneliti selanjutnya menganalisis data yang disajikan menggunakan penelitian deskriftif kualitatif, yang 
selanjutnya data di olah kemudian disimpulkan pada akhir penelitian.

\section{Results and Discussion}

Strategi komunikasi yang dilakukan Polresta Bogor Kota sebagai Komunikator yang berperan untuk menginformasikan dan mensosialisasikan terkait larangan mudik. Untuk Mencapai target yang telah ditetapkan, agar masyarakat tidak mudik saat Idul Fitri 2021, tetap di rumah, dan mobilitas di jalan tidak terlalu padat. Dalam hal ini pihak Kepolisian Resor Kota Bogor, Bagian Humas sebagai salah satu komunikator menerapkan berbagai tahapan strategi komunikasi, seperti tahap penelitian, tahap perencanaan, dan tahap pelaksanaan Tahap, tahap evaluasi dan tahap pelaporan.

\section{Tahapan Penelitian}

Tahapan yang pertama dari strategi komunikasi yaitu tahapan penelitian. Tahapan ini dilalukan Polresta Bogor Kota untuk mengetahui apa yang di butuhkan masyarakat dan untuk meminimalisir juga pemudik yang akan melakukan mudik 2021. Dalam penelitiannya Polresta merembukan dan merapatkan dengan KaPolres Bogor Kota serta jajarnya untuk merencanakan hal-hal apa yang akan dilakukan untuk meminimalisir pemudik. Melakukan berbagai sosialisasi secara massif di berbagai titik penyekatan, melakukan dan operasi zebra dan operasi ketupat untuk agar masyarakat tidak melakukan mudik.

2. Tahapan Perencanaan

Pada Tahapan kedua yaitu tahapan perencanaan tahapan ini merupakan tahapan yang di mana memiliki komponen-komponen seperti komunikator, isi pesan, media dan sasaran.

\section{a. Komunikator}

Tugas dari seorang komunikator adalah untuk menyampaikan suatu pesan kepada komunikan dengan sesuai target atau sasarannya. Dalam kegiatan menginformasikan atau mensosialisasikan tentang larangan mudik yang dilakukan oleh Polresta Bogor Kota, salah satu yang bertanggung jawab untuk menjadi komunikatornya dalam penyampaian pesan terkait larangan mudik hari raya idul fitri 2021. Dalam proses penyampaian suatu pesan pemerintah berkomunkasi degan jajaranya seperti, Pemerintah yang di wakili oleh Satgas Penanganan COVID-19, Jajaran Kemenhub, Kakorlantas Polri Irjen, Jajaran Polri khusunya Polresta Bogor kota yaitu Kapolresta Bogor kota, Kasatlantas Bogor Kota, Kasubbag Humas Bogor Kota serta jajaran lainnya dan Pemerintah daerah kepada masyarakat.

b. Pesan

Agar tujuan yang ingin dicapai dapat terlaksana dengan baik, Polresta Bogor Kota 
menggunakan berbagai metode dalam penyampaian pesan Tentang Larangan Mudik 2021. Metode yang pertama digunakan adalah metode informatif, baik secara langsung ataupun melalui suatu media di mana Polresta Bogor Kota selalu memberikan keterbukaan informasi bagi masyarakat Bogor, setiap kebijakan informasi larangan mudik ini selalu diumumkan melalui berbagai media.

Dalam memperkuat strategi komunikasi yang dilakukan oleh Polresta Bogor Kota dalam mensosialisasikan dan menginformasikan tentang himbauan larangan mudik untuk mengurangi dan mencegah penyebaran virus Covid-19 dalam strateginya memiliki strentgh (kekuatan). Kekuatan dari strategi komunikasi yang dilakukan terletak pada perencanaan, intensitas dan sumber daya yang dimililki. Setiap agenda, kegiatan dan kebijakan yang dikeluarkan sebelumnya telah melalui proses perencanaan yang baik dengan memperhatikan situasi dan kondisi yang ada. Serta jajaran Polresta Kota Bogor saling bersinergi dan bekerja sama dengan pihak-pihak lain dalam upacaya untuk mensosialisasikan dan menginformasikan himbauan terkait larangan mudik ini.

Penyusunan pesan terkait larangan mudik 2021 dalam upaya untuk pencegahan virus Covid-19 Polresta Bogor Kota Sebelum berkomunikasi dalam pengelolaan pesan. Pengelolaan pesan merupakan utama yang wajib di perhatikan. Berhasil tidaknya suatu komunikasi itu dilihat dari keberhasilan pesan yang disampaikan tersebut. Dari hasil penelitian yang peneliti dapat melalui pengamatan maupun wawancara dengan informan, dalam mengelola sebuah konten atau pesan yang akan di upload di media sosial, Hubungan masyakat Polresta Bogor Kota melalui beberapa tahap seperti, rapat dengan tim media sosial untuk membahas mengenai hal apa yang sedang dibutuhkan masyarakat.

Penyampaian pesan melalui media sosial, Humas Polresta Bogor Kota mempertimbangkan banyak hal dan memahami karakter dari komunikan atau masyarakat terlebih dahulu. Informasi yang disampaikan melalui sosial media pun dipilah dan dipilih sesuai dengan karakter dari komunikan. Untuk mengetahui apa yang sedang menjadi kebutuhan masyarakat serta ketika suatu bentuk informasi itu sudah di buat harus kordinasi juga ke Kapolresta Bogor Kota sebelum di upload ke social media. Dalam menyusun pesan selain melakukan rapat dengan tim media sosial, Humas Polresta Bogor Kota juga melihat terlebih dahulu bagaimana pasar dari pesan yang akan di sampaikan melalui media sosial. admin media sosial Humas Polresta Bogor kota melakukan memposting melalui instasory sebelum mengunggah ke media sosial. Dalam proses penyampaian informasi di salah satu media social Instagram Polresta Bogor Kota menggunakan Bahasa Indonesia yang baik dan benar serta narasi yang di tulis pun cenderung lengkap. 

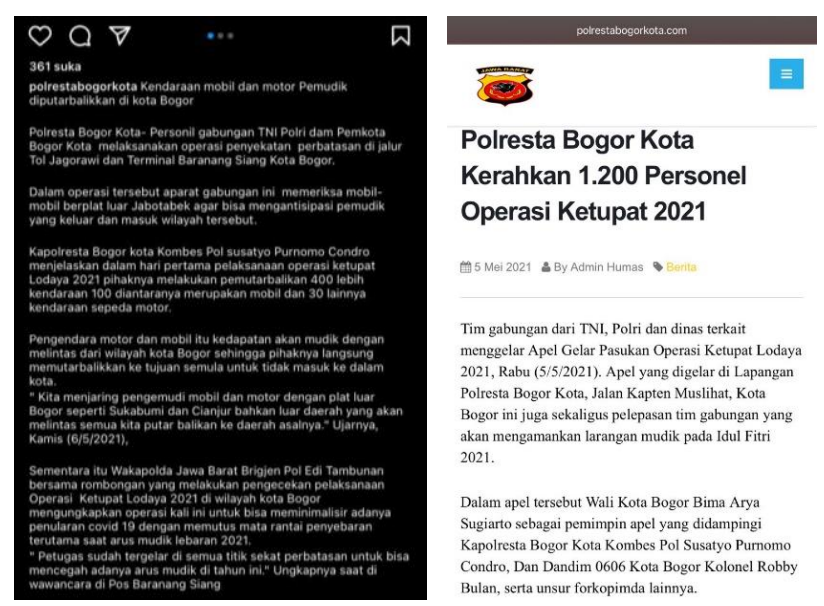

Gambar 1. Postingan isi Pesan

Sumber: Instagram Polresta Bogor Kota
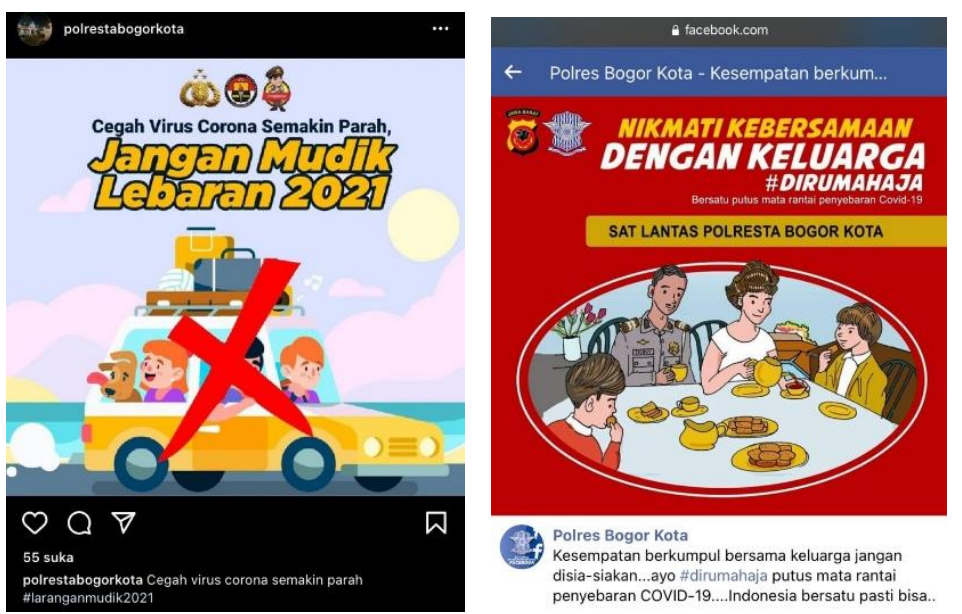

Gambar 2. Contoh Postingan Pesan persuasif

Sumber: Instagram Polresta Bogor Kota

Gambar 2 diatas merupakan salah satu contoh pesan persuasif berbentuk gambar atau meme yang di unggah ke jejaring social polresta Bogor Kota. pesan persuasif tersebut berisikan suatu ajakan agar masyarakat tetap dirumah dan tidak melakukan kegiatan mudik 2021. Dalam unggahan tersebut juga terdapat kalimat "cegah virus corona semakin parah" ini merupakan suatu pesan ajakan agar virus corona tidak menyebar semakin parah dan ini tentunya diharapkan masyarakat tidak melakukan mudik hari raya idul fitri. Melalui bentuk pesan-pesan yang disampaikan diharapkan diterima dengan baik oleh masyarakat khususnya masyarakat Bogor.

Tidak hanya itu Polresta Bogor kota untuk mensosialisasikan atau untuk menginformasikan tentang larangan mudik ini menggunakan metode informatif secara langsung dengan melalui operasi Ketupat yang di mana operasi ini dilakukan oleh Kepolisian Republik Indonesia (Polri) khusunya Polresta Bogor Kota dan jajaranya untuk mengamankan 
jalur mudik pada masa lebaran serta menginformasikan tentang larangan mudik ini kepada masyarakat. Selanjutnya Polresta Bogor Kota juga menggunakan metode repetition (pengulangan). Pesan yang disampaikan secara berulang, agar masyarakat dapat mendapatkan informasi tersebut secara terus menurus atau berulang.

c. Media

Hal menjadi Salah satu Penentuan keberhasilan strategi komunikasi adalah pemilihan media yang tepat sebagai penyampaian pesan dan faktor-faktor tertentu pun harus disesuaikan seperti isi dan sifat pesan serta target komunikannya. Dalam proses sosialisasi atau menginformasikan suatu pesan Polresta Bogor Kota menggunakan pesan persuasif dan pesan informatif. Untuk target atau sasaran dari pesan tersebut atau komunikannya adalah seluruh masyarakat baik masyarakat Bogor maupun luar Bogor.

Proses penyampain pesan tentang larangan mudik hari raya idul fitri polresta Bogor Kota menggunakan beberapa media baru berbasis internet yang dinilai lebih efektif dari media lainnya. Hal ini sangat berguna dalam penyampaian pesan-pesan tentang sosialisasi larangan mudik hari raya idufitri 2021. Untuk mensosialisasikan dan untuk memberitahukan informasi tentang larangan mudik tersebut Polresta Bogor Kota menggunakan Media social, untuk media yang digunakan pun beragam seperti Instagram, Facebook, Twitter dan WEB yang digunakan untuk memberikan informasi. Keempat media itu pada dasarnya media sosial merupakan media komunikasi yang sudah menjadi hal yang ketergantungan bagi masyarakat diera yang sekarang ini. Selain itu penggunaan media sosial memudahkan sesorang atau lembaga untuk berkomunikasi secara menyeleruh tanpa terbatas oleh waktu dan tempat.

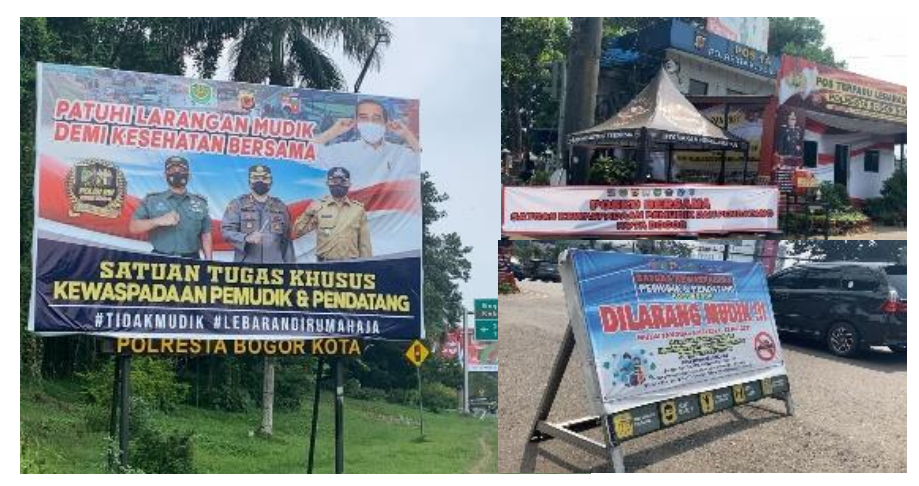

Gambar 3. Informasi menggunakan media Cetak

Selain media sosial, penggunaan media lainnya dalam kegiatan mensosialisasikan tentang larangan mudik yaitu menggunakan media cetak seperti Banner, spanduk, Poster, billboard serta media cetak lainnya yang di pajang di jalan dan disudut-sudut kota yang dilalui oleh masyarakat agar masyarakat bisa menbaca himbauwan atau informasi tersebut. Serta juga 
khususnya humas Polresta Bogor Kota melakukan press release ke media-media online yang sudah dekat, hal ini agar informasi himbauan larangan mudik ini bisa di ketahui oleh semua kalangan masyarakat di Kota Bogor maupun yang diluar kota Bogor. Serta juga bekerja sama dengan beberapa influencer untuk mensosialisasikan dan menginformasikan larangan mudik ini agar informasi terkait bisa di sampaikan secara lebih luas lagi.

\section{d. Sasaran komunikan}

Pesan ini disampaikan kepada seluruh masyarakat di seluruh Indonesia. Khusunya untuk masyarakat Bogor yang menerima informasi ini melalui media social seperti facebook, twiter, Instagram atau pun web resmi pemerintahan serta media cetak maupun yang lainnya..

\section{Tahapan Pelaksanaan}

Tahapan pelaksanaan merupakan suatu tahapan lanjutan dari tahapan perencanaan yang di mana komponen-komponen komunikasi telah di tetapkan pada tahapan perencanaan sebelumnya. Ketika sudah di tetapkan komponen-komponennya lalu pada tahapan pelaksanaan ini akan menjalankan dan menginplementasikan suatu komponen tersebut untuk mencapai suatu tujuan dari strategi komunikasi.

Pada tahapan ini, Polreta Bogor Kota selaku dari Devisi Humas Polresta Bogor Kota memanfaatkan media social seperti Instagram, Facebook, youtube dan Web untuk mensosialisasikan dan menginfrormasikan mengenai larangan Mudik hari raya idul fitri 2021 dengan membuat suatu postingan-postingan atau pun video-video singkat tentang larangan mudik tersebut.

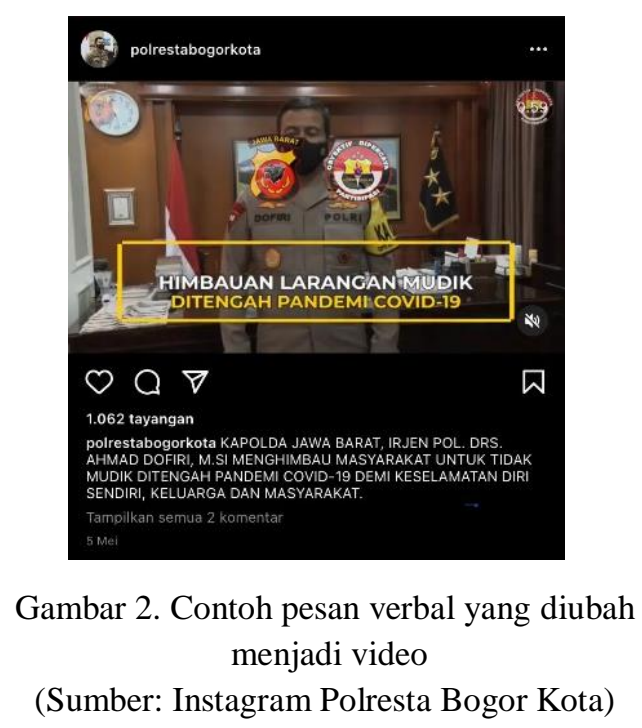

Gambar diatas merupakan salah satu contoh unggahan yang ada di akun Instagram Polresta Bogor Kota yang di mana pesan tersebut berupa video yang disampaikan oleh Pol. Drs. Ahmad Dofiri, menyampaikan informasi agar masyarakat tetap dirumah dan tidak melakukan kegiatan mudik. Cara ini dilakukan oleh Polresta Bogor Kota agar pesan yang 
disampaikan mengenai larangan mudik 2021 bisa disampaikan ke masyarakat Bogor maupun luar Bogor.

Polresta Bogor Kota dalam pelaksanaannya di lapangan melakukan suatu kegiatan Operasi Ketupat yang di mana Operasi ini melibatkan seluruh anggota kepolisian untuk melakukan sosialisasi dan menginformasikan kepada masyarakat tentang larangan mudik dan juga pada operasi Ketupat ini tim Polresta Bogor Kota melakukan Posko Penyekatan di 6 titik di Kota Bogor di antaranya di dekat pintu tol Baranang siang, di simpang BORR, di jalan Wangun Simpang Ciawi, di Simpang Gunung Batu, di simpang Yasmin dan di Simpang Cifor. Setiap Kendaraan yang melewati titik dari penyekatan akan dimintai kelengkapan identitas dan surat keterangan negative Covid-19. Pada operasi ini melibatkan beberapa anggota personil seperti personil yang di turunkan terkait tentang penanganan peniadaan mudik itu lebih dari 1000 personil di antaranya sekitar 283 orang personil Dishub non ASN, 63 orang ASN, untuk Polri 779 personil, Kodim 105 personil, Denpom 16 personil, korganda 37 personil Pada Mudik lebaran idul fitri 2021 Hal menjadi bagian strategi yang digunakan oleh Polresta Bogor Kota untuk mencegah Pemudik yang masuk dan untuk mencegah mobiltas yang tinggi di jalan guna pencegahan Penyebaran Covid-19. Operasi ketupat ini telah memutar balikan kendaraan roda dua dan roda empat pertanggal 6 mei 2021 sampai 17 mei 2021 sebanyak 2600 kendaraan roda dua diputarbalikan dan sebanyak 9009 roda empat diputar balikan selama pemberlakukan larangan mudik.

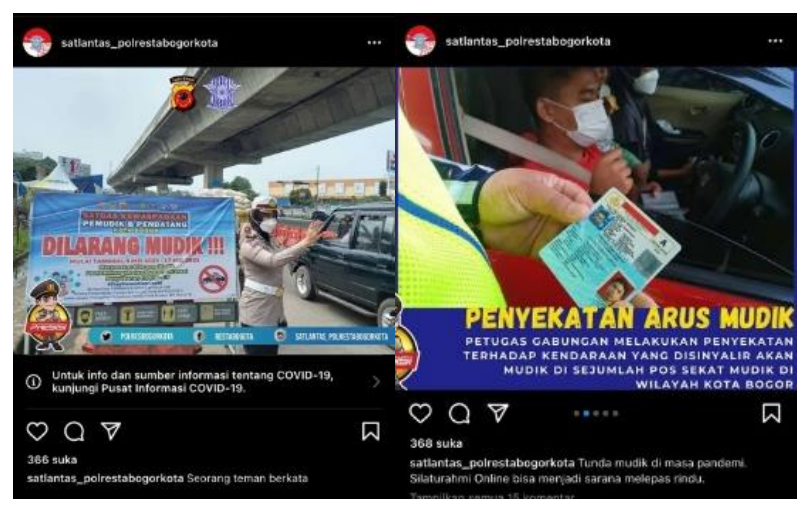

Gambar 3. Penyekatan Arus Mudik

(Sumber: Instagram Satlantas Polresta Bogor Kota)

Di samping itu juga, Polresta Bogor Kota melakukan kerja sama dengan beberapa media local seperti radio, koran dan beberapa influencer guna informasi mengenai larangan mudik ini bisa tersampaikan secara luas kepada masyarakat.

4. Tahap Evaluasi

ketika tahapan strategi komunikasi sebelumnya sudah dilaksanakan kemudian tahapan 
berikutnya adalah tahapan evaluasi. Pada tahapan strategi komunikasi ini kegiatan yang sudah dilakukan dan dijalankan akan di evaluasi untuk mencapai suatu tujuan strategi komunikasi. Hasil kegiatan evaluasi tersebut biasanya meliputi implementasi dan komponen-komponen dari strategi komunikasi itu sendiri.

Skema tahapan strategi komunikasi yang dijalankan oleh Polresta Bogor Kota dalam tahapan evaluasi terbagi ke dalam dua tahapan evaluasi yaitu eksternal dan internal. Untuk tahapan evaluasi eksternal Polresta Bogor Kota menggunakan sistem berbasis WEB yaitu IMM. IMM merupakan kepanjangan dari Intelligence Media Management yang dimana media ini berperan untuk menyebarkan informasi tentang kinerja Polri dalam bentuk suatu berita ataupun lainnya untuk masyarakat (Polri, 2018). Aplikasi ini sangat berperan penting dalam fungsi kehumasan. Dari portal web ini lah bisa mengetahui keefektivan dari penyampaian informasi Polri termasuk polresta Bogor Kota sehingga bisa di evaluasi dan dianalisa ketika berita atau informasi yang disampaikan itu kurang efektif.

Selanjutnya tahapan evaluasi Internal, Polresta Bogor Kota melakukan evaluasi rekapan suatu kegiatan yang dilakukan setiap hari, minggu dan bulan. Dari hasil rekapan tersebut nantinya akan di Analisa suatu kegiatan tersebut dan ketika ada suatu kegiatan yang kurang efektiv kekurangannya akan di Analisa.

\section{Tahap Pelaporan}

Selanjutnya adalah tahapan pelaporan, tahapan ini merupakan tahapan terakhir dari rangkaian tahapan strategi komunikasi. tahapan pelaporan bertujuan untuk menjelaskan hasil yang telah diperoleh dari tahapan-tahapan sebelumnya yang sudah dijalankan oleh lembaga ataupun organisasi. Tahapan ini dilaksanakan agar bisa mengetahui hasil-hasil yg telah dijalankan. Pada tahapan pelaporan mengenai larangan mudik hari raya idulfitri 2021 ini Polresta Bogor Kota mengunggah ke WEB IMM (Intelligence Media Management) serta ke social media lalu polresta juga membuat laporan-laporan kegiatan ke dalam buku atau semacam majalah yang berisikan berita dan lain, nah laporan-laporan tersebut bisa dipakai ketika dibutuhkan.

\section{Conclusion}

Hasil dari kesimpulan pembahasan di atas adalah strategi komunikasi yang dilakukan oleh Polresta Bogor Kota sebagai Selaku Komunikator dalam mensosialisasikan dan menginformasikan terkait penyampaian pesan kepada masyarakat mengenai larangan mudik cukup efektif yaitu menggunakan pesan bersifat informatif dan persuasif serta dalam strateginya sudah melalui perencanaan sebelum melakukan dan melaksanakan tugas. Lalu 
Kepoliasian dalam menghadapi Mudik 2021 melakukan Evaluasi rutin yang dilakukan tiap minggu, secara teknik kepolisian sudah mempersiapkan dengan matang. Dalam pelaksanaanya untuk mencegah para pemudik pihak kepolisian juga menggelar giat seperti operasi zebra dan operasi ketupat dengan melalukan penyekatan di beberapa titik di kota Bogor agar pemudik tidak bisa masuk ataupun keluar dengan bebas ke Kota Bogor. Hal ini dilakukan untuk menekan laju mobilitas di jalan dan keramaian.

Hal yang perlu diperhatikan berikutnya yaitu sebaiknya pihak media sosial Kepolisian Bogor Kota lebih meningkatkan lagi strategi komunikasi melalui social media seperti Instagram Facebook serta lebih memperdayakan lagi situs Website nya lalu hal ini bertujuan agar pesan yang disampaikan bisa lebih luas dan menyeluruh lagi dan sebaiknya juga akunakun medial sosial tersebut lebih di branding serta lebih di publikasikan lagi agar masyarakat memfollow dan mengetahui informasi terkait lalu lintas dan lain sebagainya agar bisa menjamin efektifitas pesan yang disampaikan tersebut.

\section{References}

Ari Purwanto Sarwo Prasojo, Yulinda Nurul Aini, D. K. (2020). Potensi Pola Aliran Mudik Pada Masa Pandemi Covid-19. Jurnal Kependudukan Indonesia , Edisi Khusus Demografi Dan COVID-19, 21-26. https://ejurnal.kependudukan.lipi.go.id/index.php/jki/article/view/579/pdf

Bulkis, A. Y. (2018). Strategi Komunikasi Pemasaran Dalam Meningkatkan Jumlah Pengguna Jasapada Pt. Hikmah Perdana Tourdi Makassar. Departemen ilmu Komunikasi fakultas Ilmu Sosial Dan Ilmu Politik universitas Hasanuddin makassar.

Effendy, O. U. (2009). Ilmu Komunikasi teori dan praktek. Pt Remaja Rosdakarya.

Kominfo. (2021). Larangan Mudik Kurangi Risiko Akibat Covid-19. Kementrian Komunikasi Dan Informatika. https://www.kominfo.go.id/content/detail/33520/larangan-mudik-kurangi-risikoakibat-covid-19/0/berita

Kompas Pedia. (2021). Lonjakan Kasus Covid-19 Pasca Libur Lebaran 2021.

https://kompaspedia.kompas.id/baca/paparan-topik/lonjakan-kasus-covid-19-pasca-libur-lebaran2021

Moleong, L. J. (2017). Metodologi Penelitian Kualitatif (36th ed.). PT. REMAJA ROSDAKARYA.

Polri. (2018). pengantar Intelligence Media Management(Imm). https://lemdik.polri.go.id/index.php?p=fstream\&fid=5176\&bid=390

Satgas Covid 19. (2021). Addendum Surat Edaran Nomor 13 Tahun 2021 Tentang Peniadaan Mudik Hari Raya Idul Fitri Tahun 1442 Hijriah Dan Upaya Pengendalian Penyebaran Corona Virus Disease 2019 (Covid-19) Selama Bulan Suci Ramadhan 1442 Hijriah. Satgas Covid 19. https://covid19.go.id/storage/app/media/Regulasi/2021/April/Addendum Surat Edaran KaSatgas No. 13 Tahun 2021 tentang Peniadaan Mudik Hari Raya Idul Fitri Tahun 1442H dan Upaya Pengendalian Penyebaran COVID-19 Selama Bulan Suci Ramadhan 1442H.pdf

Yunus, E. (2016). Manajen Strategi. CV andi offset. 